Primljen / Received: 23.5.2013.

Ispravljen / Corrected: 28.12.2013.

Prihvaćen / Accepted: 6.3.2014.

Dostupno online / Available online: 10.4.2014.

\title{
Effect of initial conditions on strength of unsaturated compacted loess soil
}

\section{Authors:}

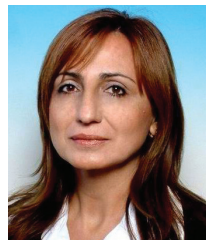

Gordana Hadži-Niković, PhD. Geol.

University of Belgrade

Faculty of Mining and Geology

ghnikovic@rgf.bg.ac.rs

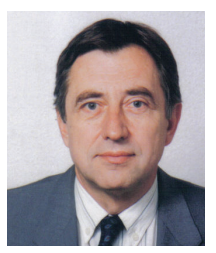

Prof. Slobodan Čorić, PhD. Geol.

University of Belgrade

Faculty of Mining and Geology

sloba.coric@gmail.com

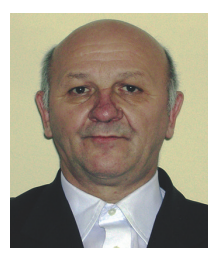

Assoc.Prof. Laslo Čaki, PhD. Geol.

University of Belgrade

Faculty of Mining and Geology

laslo.caki@rgf.bg.ac.rs

\section{Gordana Hadži-Niković, Slobodan Ćorić, Laslo Čaki}

\section{Effect of initial conditions on strength of unsaturated compacted loess soil}

The influence of grain size distribution, initial moisture, dry bulk density, and capillary suction on an increase in shear strength of unsaturated compacted silty loess soil is presented in the paper. The unsaturated soil strength is determined via the experimentally determined dependencies between the moisture-capillary suction and the effective shear strength parameters for saturated soil, $c^{\prime}, \varphi^{\prime}$. It is demonstrated that the influence of capillary suction, moisture and dry bulk density on the strength of unsaturated compacted soil reduces with an increase of grain size in soil.

Key words:

unsaturated soil, capillary suction, shear strength, initial conditions, compacted soil

Prethodno priopćenje

Gordana Hadži-Niković, Slobodan Ćorić, Laslo Čaki

\section{Utjecaj početnih uvjeta na čvrstoću nezasićenog zbijenog lesnog tla}

U radu je prikazan utjecaj granulometrijskog sastava, početne vlažnosti, suhe zapreminske težine i veličine kapilarnog usisa na uvećanu čvrstoću smicanja nezasićenog zbijenog prašinastog lesnog tla. Čvrstoća nezasićenog tla je određena na osnovi eksperimentalno ispitanih ovisnosti vlažnost-kapilarni usis i efektivnih parametara čvrstoće smicanja zasićenog tla, c', $\varphi^{\prime}$. Pokazano je da s povećanjem veličine zrna u tlu, opada utjecaj kapilarnog usisa, vlažnosti i suhe zapreminske težine na čvrstoću nezasićenog zbijenog tla.

Ključne riječi:

nezasićeno tlo, kapilarni usis, čvrstoća smicanja, početni uvjeti, zbijeno tlo

Vorherige Mitteilung

Gordana Hadži-Niković, Slobodan Ćorić, Laslo Čaki

\section{Einfluss der Anfangsbedingungen auf den Widerstand ungesättigten verdichteten Lössbodens}

In dieser Arbeit ist der Einfluss der Kornzusammensetzung, der Ausgangsfeuchte, der Rohdichte und der kapillaren Saugwirkung auf die erhöhte Scherfestigkeit von ungesättigtem verdichtetem schluffigem Lössboden dargestellt. Der Widerstand des ungesättigten Bodens wird aufgrund der experimentell ermittelten Verhältnisse von Feuchtigkeit und kapillarer Saugwirkung und der effektiven Scherfestigkeitswerte $c^{\prime}, \varphi^{\prime}$ des gesättigten Bodens bestimmt. Mit zunehmender Korngröße ist ein verringerter Einfluss der kapillaren Saugwirkung, der Feuchtigkeit und der Rohdichte auf den Widerstand ungesättigten verdichteten Bodens festgestellt. 


\section{Introduction}

Unsaturated soils are naturally unsaturated soils that are situated above the ground water level, just like all artificially compacted soils [1]. These soils are exposed to combined changes in moisture and air content in pores. All moisture changes in unsaturated soil are followed by circulation of water and air [2]. Unsaturated soil is a four-phase system that is composed of: solid particles, water, air, and air-water contact surface. Water forms meniscuses with curved surfaces in the zone of contact with solid particles, which is similar to the meniscus that occurs when water rises in a capillary tube [3]. The surface tension at the air-water contact membrane ensures that the pressure of water is lower compared to the outside air pressure. Then the matric suction is defined as the difference between the air pressure from the external side of the meniscus $\left(u_{a}\right)$ and water pressure within the meniscus $\left(u_{w}\right)$ i.e. the matric suction is $u_{a}-u_{w}$. The matric suction in soil increases the soil strength and hence greatly reduces the intensity of active soil pressure exerted on the retaining structure, while greatly increases the force of passive resistance, critical height of vertical excavation, ultimate bearing capacity, and stability of natural and man-made slopes. Thus conventional analyses of lateral earth pressures, allowable bearing capacity and slope stability, especially for soil made of silty and silty-clayey sediments, often give unrealistically low factors of safety $[1,4]$ if matric suction - regarded as an independent stress state variable - is not taken into account.

Mechanical properties of unsaturated soil have not been sufficiently investigated despite the fact that many problems encountered in geotechnical practice are solved precisely in unsaturated soil, and although it has been proven that even a small amount of suction increases stability of slopes [5] and the height of vertical excavations [6]. The reason for that must be sought in the fact that results, obtained on the basis of geostatic analyses with saturated soil parameters, are conservative, i.e. give lower factors of safety. But also in the fact that laboratory tests for the determination of shear strength of unsaturated soil are time-consuming, expensive and require modification of conventional laboratory equipment.

Results obtained by testing shear strength of unsaturated loess sediments in the area of Belgrade are presented in the paper. These results are based on the moisture - matric suction dependence, SWRC (soil water retention curve), and effective shear strength parameters for saturated soil, $c^{\prime}$, $\varphi^{\prime}$, according to the Vanapalli model [7]. The relationships between moisture and matric suction were determined by laboratory testing of moisture extraction from soil samples under various pressures in the semi-permeable plate extractor (15 bar Pressure Plate Extractor 1500 - Soilmoisture Equipment Corporation, Santa Barbara, California). The testing was conducted in accordance with the standards set by the American Society for Testing and Materials (ASTM) [8, 9].

The testing was conducted on artificially prepared samples, and this for two reasons. Firstly, the testing with artificial samples enables analysis of the influence of Initial conditions on typical moisture-matric suction relationships, and on the shear strength of unsaturated compacted soil. Secondly, all phenomena of unsaturated soil become particularly prominent in embankments that are built according to specially defined initial conditions. Soils compacted at different moisture and density values, are considered to be different types of soil [10]. The following loess soil was tested: silty loess, series $A$, loess with a higher fine-grained content, series $B$, and loess with a higher coarse-grained content, series C. This testing of artificial loess samples enabled analysis of the influence exerted by individual parameters such as: grain size distribution, initial moisture and structure of soil, on the shear strength of unsaturated soil. The results were compared with results obtained by authors from other countries and a satisfactory correspondence was obtained [11].

\section{Basic characteristics of unsaturated soil}

While mechanical properties of saturated soil are determined by means of effective stress $\left(\sigma-u_{w}\right)$, [12], two independent stress state variables, i.e. net normal stress $\left(s-u_{a}\right)$, and matric suction $\left(u_{a}-u_{w}\right)[13]$, are needed as stress variables for the determination of mechanical properties of unsaturated soil.

The primary constitutive relationship, indispensable during interpretation of mechanical properties of unsaturated soil, is the moisture-matric suction relationship, or the degree of saturation matric suction relationship, SWRC [14]. Due to similarity between the influence of matric suction change on the change in the degree of saturation on the moisture-suction curve, and the influence of matric suction, as a stress variable, on the shear strength [15], a correlation was established between the soil behaviour at experimental shear and soil behaviour at experimental drying in extractor [16]. Many authors have proposed various equations for shear strength of unsaturated soil based on typical moisturematric suction relationships and effective shear strength parameters for saturated soil, $c^{\prime}, \varphi^{\prime}[17,18]$.

Soil parameters significant for the determination of unsaturated shear strength: air-entry value $\left(u_{a}-u_{w}\right)_{b^{\prime}}$, residual degree of saturation $\mathrm{S}_{\text {rez' }}$ and pore size distribution index $\lambda$, can easily be defined from the moisture-matric suction diagram, if the degree of saturation is expressed as an effective degree of saturation $-S_{e}[19]$ :

$S_{e}=\frac{S_{r}-S_{r e z}}{1-S_{r e z}}$

$\mathrm{S}_{\mathrm{e}}$ - effective degree of saturation,

$\mathrm{S}_{\mathrm{r}}$ - degree of saturation for a specified matric suction value, determined from the test in extractor,

$\mathrm{S}_{\text {rez }}$ - residual degree of saturation that is equal to the degree of saturation at which a further increase in matric suction would not affect its change.

In order to define the constitutive relationship between the moisture and matric suction, the relationship of effective degree of saturation on the matric suction must be defined for a specific value of the residual degree of saturation, and 
this in such a way that this relationship is linear for matric suction values that exceed the air-entry value, i.e. $\left(u_{a}-u_{w}\right)>\left(u_{a}-\right.$ $\left.u_{w}\right)_{b}$. Then the relationship between the effective degree of saturation and the matric suction is defined by the expression:

$S_{e}=\left[\frac{\left(u_{a}-u_{w}\right)_{b}}{\left(u_{a}-u_{w}\right)}\right]^{\lambda}$

where $\lambda$ - pore size distribution index that is defined as a negative slope inclination of the linear part of relationship "curve" is better than "dependence betweeen the" effective degree of saturation - matric suction curve.

Based on thus obtained effective degrees of saturation ( $\mathrm{S}_{\mathrm{e}}$ ) and effective shear strength parameters for saturated soil $c^{\prime}$ and $\varphi^{\prime}$, we can derive the following relationships between the unsaturated shear strength and matric suction [7]:

$\tau_{f}=\left[c^{\prime}+\left(\sigma-u_{a}\right) \tan \varphi^{\prime}\right]+\left(u_{a}-u_{w}\right) \tan \varphi^{\prime} S_{e}$

$\tau_{f} \quad$ - shear strength of unsaturated soil for the value of matric suction $\left(u_{a}-u_{w}\right)$,

$c^{\prime}, \varphi^{\prime} \quad$ - effective shear strength parameters for saturated soil, $\left(\sigma-u_{a}\right)-$ normal net stress,

$\left(u_{a}-u_{w}\right)$ - matric suction value for which shear strength for unsaturated soil is determined.

The shear strength parameter for unsaturated soil, $\varphi^{\mathrm{b}}$, as related to the matric suction $\left(u_{a}-u_{w}\right)$, can also be expressed via the effective degree of saturation by means of the following equation [7]:

$\tan \varphi^{b} f n\left(u_{a}-u_{w}\right)=S_{e} \tan \varphi^{\prime}$

\section{Soil characteristics and laboratory testing program}

The loess soil was selected to determine the influence of grain size distribution, initial moisture and bulk density, on the unsaturated strength of compacted soil. The outcropping zone of the Belgrade territory is dominantly formed of loess sediments, frequently with several horizons of loess. These layers often have to be compacted during realization of geotechnical works in the scope of construction of various structures and, as this activity occurs near the ground surface, and as the soil remains in an unsaturated condition, it was especially significant to determine how different initial conditions of these environments affect their unsaturated strength. For that reason, all tests were conducted on loess sediments from the Zemun area: in the dominantly silty loess (series A), in loess with a higher content in fine grains (series B), and in loess with a very high content in coarse grains (series C). Identification-classification test results obtained on samples from each of these series are presented in Table 1 , while grain size distribution diagrams are given in Figure 1.

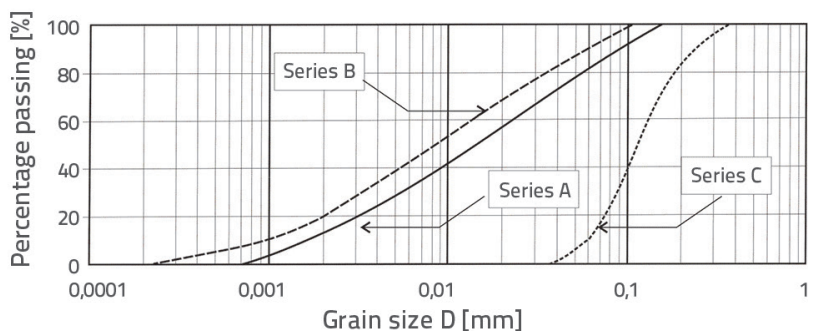

Figure 1. The grain size distribution curves for samples from various series

First, artificial samples were prepared for different soil types (series $A, B$ and $C$ ) and then drainage tests were made in extractor with a semi-permeable plate in order to determine the SWRC, as well as direct shear tests on saturated samples, in order to determine effective shear strength parameters $c^{\prime}$ and $\varphi^{\prime}$.

\subsection{Preparation of samples}

The preparation of artificial samples started with an optimum moisture testing according to SRPS standard [20]. After determination of the optimum moisture, $w_{\text {opt' }^{\prime}}$ pairs of points were determined for each series on the dry and moist branch, which differed by about $\pm 2-3 \%$ of moisture with respect to the optimum moisture. Thus three point pairs from the Proctor test diagram were determined for each series (dry sample: $\mathrm{w}_{\mathrm{s}^{\prime}}$ $\gamma_{d s^{\prime}}$ optimally moist sample: $w_{\text {opt' }} \gamma_{\text {dmax, }}$ and moist sample: $w_{v^{\prime}} \gamma_{d v}$ ). Then a greater quantity of samples with these moisture values was prepared as all subsequent tests were conducted using previously prepared samples of "required" moisture, and required bulk densities of samples were obtained by static compaction of material in a mould of known volume.

The sample pre-loading is not possible during the drainage of samples in the ceramic-plate extractor. On the other hand, samples were exposed to vertical consolidation pressure $s=50$ $\mathrm{kPa}$ during determination of effective strength parameters by the direct shear CD testing. To overcome the problem regarding difference in testing conditions, samples prepared for testing in extractor were "overconsolidated" with the equivalent net normal stress (the so called pseudo net normal stress) in oedometer

Table 1. Identification-classification test results

\begin{tabular}{|c|c|c|c|c|c|c|c|c|c|c|c|}
\hline \multirow[b]{2}{*}{ Sample series } & $\gamma$ & $\gamma_{d}$ & \multirow{2}{*}{$\begin{array}{c}\mathbf{w} \\
\%]\end{array}$} & \multirow{2}{*}{$\begin{array}{c}\mathbf{G}_{\mathrm{s}} \\
-\end{array}$} & \multirow{2}{*}{ e } & $S_{r}$ & $w_{L}$ & $I_{p}$ & \multicolumn{3}{|c|}{ Fraction [\%] } \\
\hline & \multicolumn{2}{|c|}{$\left[\mathrm{kN} / \mathrm{m}^{3}\right]$} & & & & & {$[\%]$} & & $\begin{array}{c}<0,002 \\
{[\mathrm{~mm}]}\end{array}$ & $\begin{array}{c}0,06-0,002 \\
{[\mathrm{~mm}]}\end{array}$ & $\begin{array}{l}>0,06 \\
{[\mathrm{~mm}]}\end{array}$ \\
\hline Series A & 16,4 & 14,2 & 16,0 & 2,70 & 0,901 & 45 & 32 & 10 & 12 & 70 & 18 \\
\hline Series B & 20,2 & 17,1 & 17,9 & 2,75 & 0,605 & 81 & 35 & 15 & 20 & 70 & 10 \\
\hline Series C & 17,5 & 15,0 & 16,7 & 2,74 & 0,827 & 55 & 24 & 7 & - & 10 & 90 \\
\hline
\end{tabular}


Table 2. Initial conditions for dry, optimally wet and wet compacted samples from different series

\begin{tabular}{|c|c|c|c|}
\hline \multirow{2}{*}{ Sample series } & \multicolumn{3}{|c|}{ Initial conditions of moisture and dry bulk weight } \\
\hline & Dry sample & Optimally wet sample & Wet sample \\
\hline Series A & $\begin{array}{c}w_{s}{ }^{A}=15,0 \% \\
\gamma_{d s}{ }^{A}=17,1 \mathrm{kN} / \mathrm{m}^{3}\end{array}$ & $\begin{array}{c}\mathrm{w}_{\mathrm{opt}}{ }^{\mathrm{A}}=17,5 \% \\
\gamma_{\mathrm{dmax}}{ }^{\mathrm{A}}=17,5 \mathrm{kN} / \mathrm{m}^{3}\end{array}$ & $\begin{array}{c}w_{v}{ }^{A}=20,0 \% \\
\gamma_{d v}{ }^{A}=17,0 \mathrm{kN} / \mathrm{m}^{3}\end{array}$ \\
\hline Series B & $\begin{array}{c}w_{s}{ }^{B}=16,0 \% \\
\gamma_{d s}{ }^{B}=16,8 \mathrm{kN} / \mathrm{m}^{3}\end{array}$ & $\begin{array}{c}w_{o p t}{ }^{B}=19,0 \% \\
\gamma_{d \max }{ }^{B}=17,2 \mathrm{kN} / \mathrm{m}^{3}\end{array}$ & $\begin{array}{c}w_{v}{ }^{B}=22,0 \% \\
\gamma_{d v}{ }^{B}=16,2 \mathrm{kN} / \mathrm{m}^{3}\end{array}$ \\
\hline Series C & $\begin{array}{c}w_{s}{ }^{c}=11,5 \% \\
\gamma_{d s}{ }^{c}=17,8 \mathrm{kN} / \mathrm{m}^{3}\end{array}$ & $\begin{array}{c}\mathrm{w}_{\mathrm{opt}}{ }^{\mathrm{c}}=14,0 \% \\
\gamma_{\mathrm{d} \max }{ }^{c}=18,1 \mathrm{kN} / \mathrm{m}^{3}\end{array}$ & $\begin{array}{c}w_{v}{ }^{c}=16,5 \% \\
\gamma_{d v}{ }^{c}=17,5 \mathrm{kN} / \mathrm{m}^{3}\end{array}$ \\
\hline
\end{tabular}

during 24 hours so that, after release of pressure, and after extraction of "small" samples and their placing in extractor, they would have the same porosity coefficient, as if the consolidation were conducted under the load of $\sigma=50 \mathrm{kPa}$. This resulted in formation of "artificial" samples for drainage under pressure in extractor, and for direct shear CD tests, which exhibited, for each series, the known moisture, dry bulk density, and porosity coefficient.

Identification-classification tests, Proctor tests, preparation of samples by static compaction to required density, consolidation of samples in oedometer, and direct shear CD tests, were conducted in the accredited Soil Mechanics Laboratory of the Highway Institute in Belgrade, in compliance with applicable national SRPS standards. Sample drainage tests in extractor, with ceramic plates of different porosity and under different pressures, were conducted at the Soil Physics Laboratory of the Faculty of Agriculture in Belgrade.

\subsection{Drainage of samples in extractor with semi- permeable plate under pressure (pressure plate test)}

Samples were tested in extractor with a semi-permeable plate in order to determine relationships between the moisture and matric suction. The principle of sample drainage in extractor with ceramic plate can be described as follows: if a specific pressure is applied onto a water-saturated sample, all water bound to soil, with the water bonding force equal to or smaller than the pressure, will be extracted from the soil mass. In other words, the greater the pressure the more water is extruded from the soil and the extruded quantity of water will always be proportional to the stress "maintained" in the soil. Tests whose results are presented in the paper were conducted in extractor under various pressures ranging from 20 to $1500 \mathrm{kPa}$. Ceramic plates that were used as a support for samples exhibited various pore sizes, which enabled a great range of pressures in the apparatus. The total of four plates, with different pore sizes, was used.

Tests were conducted in keeping with standards specified by the American Society for Testing and Materials (ASTM) and the objective was to determine dependence between the moisture and capillarity using extractor. In this respect, the standard $D$ 2325-68 was used for coarse grained and medium grained soil and for suction forces from 10 to $100 \mathrm{kPa}$, while D 3152-72 was used for fine-grained soil and for suction forces ranging from
100 to $1500 \mathrm{kPa}$. Soil samples, $56.5 \mathrm{~mm}$ in diameter and $9.0 \mathrm{~mm}$ in height, were saturated by capillary ascent in a recipient with distilled water until occurrence of free water on the top surface of samples or in the time interval of 24 hours. Saturated samples were placed on the (also saturated) porous ceramic plate in extractor. No collapse was noted during saturation. However, a slight swelling was noted at some samples, but was not taken into account during determination of the degree of saturation. After completion of all tests, the degree of saturation was defined retroactively for all matric suction values to which samples were exposed. Mean results of drainage testing in extractor with ceramic plate are presented tabularly and graphically in the following sections.

\subsection{Determination of shear strength for saturated soil}

Shear strength parameters for effective stress values can be determined from the direct shear test or triaxial compression. Based on results presented in literature, and according to recommendations given by professor Vanapalli [21], the direct shear CD test is usually used. That is why effective shear parameters were determined by the slow direct shear CD test, compliant with the applicable standard SRPS [22].

Shear strength parameters for effective stresses: cohesion $\left(c^{\prime}\right)$ and angle of shearing resistance $\left(\varphi^{\prime}\right)$, were obtained for statically compacted samples with different initial moisture values and different dry density values. Samples were consolidated under pressure of $\sigma=50 \mathrm{kPa}$ during twenty-four hours. Samples with pre-defined initial moisture, density and porosity coefficient values were tested under normal stress values of 50,100 and $200 \mathrm{kPa}$. Consolidated samples were sheared at the rate of $0.0125 \mathrm{~mm} / \mathrm{min}$, which enabled drainage during the testing, as the sample is made of silty soil.

During the direct shear test, natural connections are broken along the shearing surface of all tested samples, including physical separation within samples, regardless of their initial level of moisture. This enables us to conclude that practically the entire resistance due to soil structure is eliminated during the drained shear, and that the sample compaction occurs. The dispersion increases with an increase in force applied, and with an increase in the bulk density of soil. As here we have small differences in dry bulk densities of samples from the same series (from 17.0 to $17.5 \mathrm{kN} / \mathrm{m}^{3}$ for the series A samples, from 16.2 to $17.2 \mathrm{kN} / \mathrm{m}^{3}$ for 


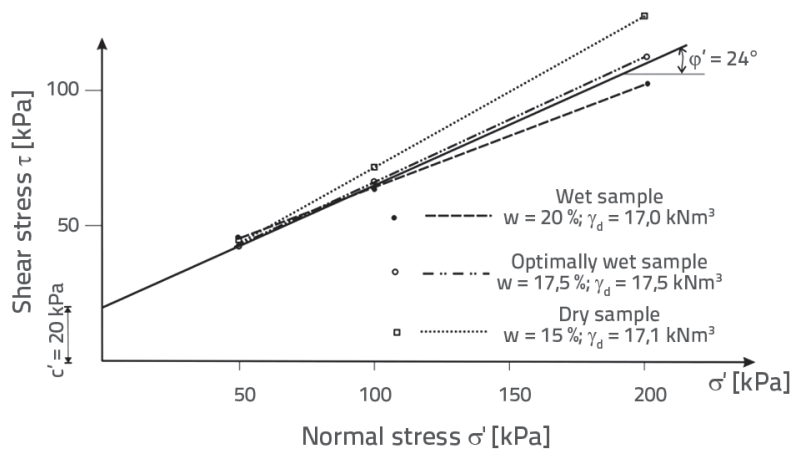

Figure 2. Average effective shear strength parameters for the series A samples

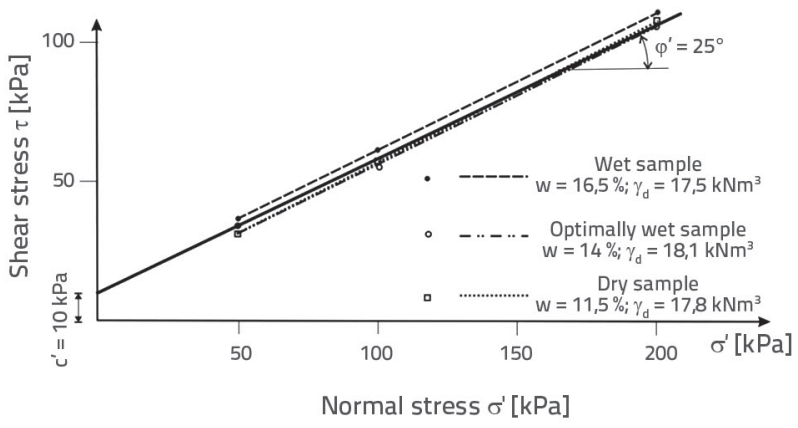

Figure 4. Average effective shear strength parameters for the series C samples

the series B samples, and from 17.5 to $18.1 \mathrm{kN} / \mathrm{m}^{3}$ for the series C samples), the shear results for samples with different initial conditions, which belong to the same soil series, are quite similar.

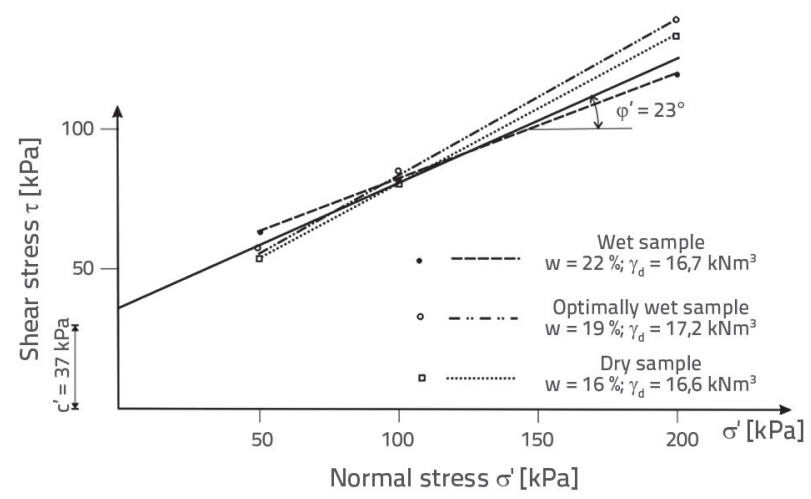

Figure 3. Average effective shear strength parameters for the series B samples

If smaller dispersions - deviations in failure envelopes - are neglected, the following average shear strength values are obtained for effective stresses, $c^{\prime}$ and $\varphi^{\prime}$ :

- for the series A loess: $c^{\prime}=20 \mathrm{kPa} \mathrm{i} \varphi^{\prime}=24^{\circ}$, (Figure 2)

- for the series B loess: $c^{\prime}=37 \mathrm{kPa} i \varphi^{\prime}=23^{\circ}$, (Figure 3)

- for the series C loess: $c^{\prime}=10 \mathrm{kPa} i \varphi^{\prime}=25^{\circ}$, (Figure 4)

\section{Analysis of test results}

\subsection{Variation of degree of saturation}

Changes in degree of saturation $\left(\mathrm{S}_{\mathrm{r}}\right.$ ) and effective degree of saturation $\left(\mathrm{S}_{\mathrm{e}}\right)$ and the matric suction $\left(\mathrm{u}_{\mathrm{a}}-\mathrm{u}_{\mathrm{w}}\right)$ for artificially prepared samples with different initial conditions, are presented in Tables 3,4 and 5. The residual degree of saturation $\left(\mathrm{S}_{\mathrm{rez}}\right)$ must be known for the determination of the effective

Table 3. Variation of degree of saturation with matric suction for the series $A$ artificial samples

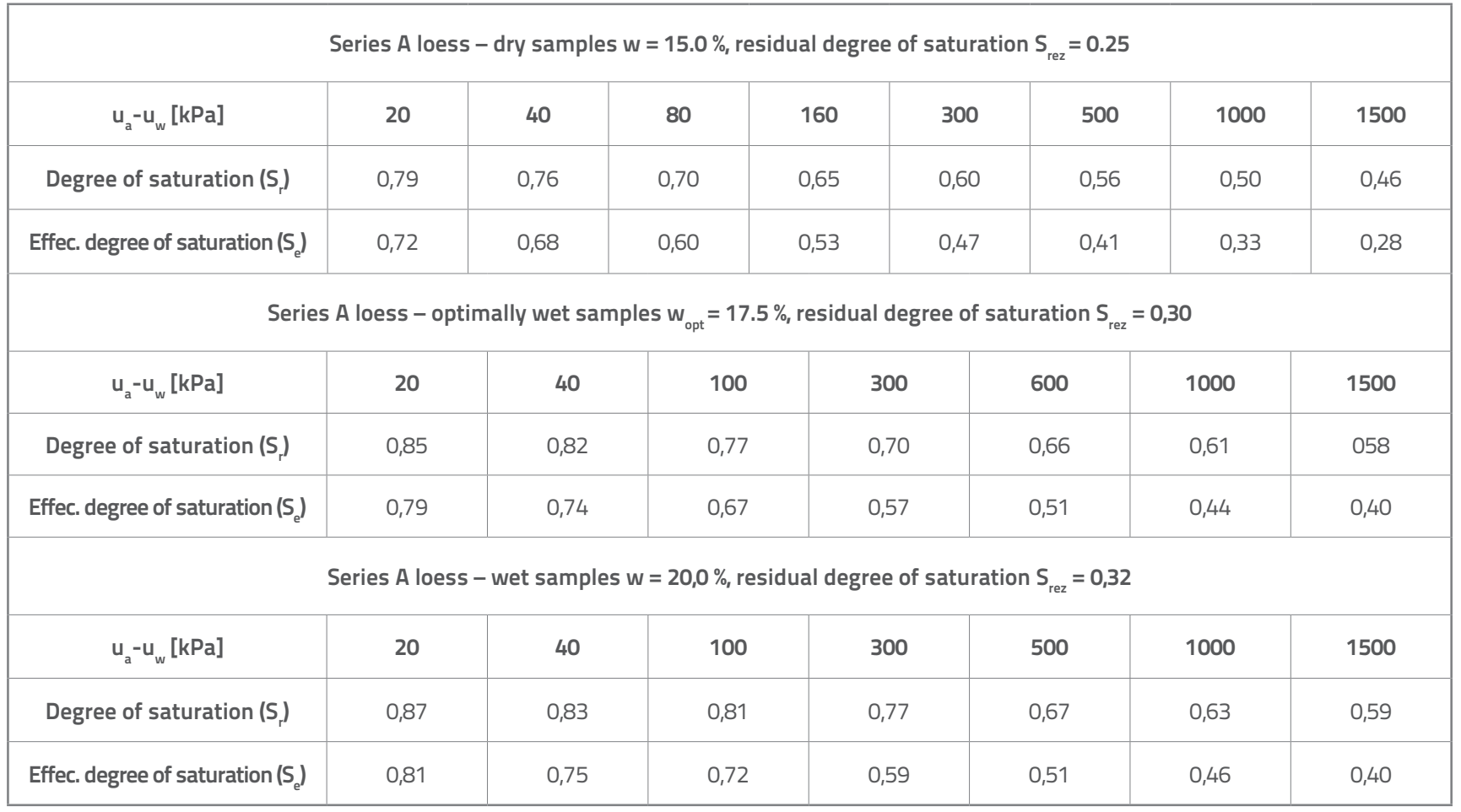


Table 4. Variation of degree of saturation with matric suction for the series B artificial samples

\begin{tabular}{|c|c|c|c|c|c|c|c|c|c|c|}
\hline \multicolumn{11}{|c|}{ Series B loess - dry samples $w=16,0 \%$, residual degree of saturation $S_{\text {rez }}=0,40$} \\
\hline$u_{a}-u_{w}[k P a]$ & 20 & 40 & 80 & 120 & 200 & 300 & 500 & 700 & 900 & 1300 \\
\hline Degree of saturation (S) & 0,86 & 0,80 & 0,76 & 0,70 & 0,68 & 0,65 & 0,61 & 0,59 & 0,55 & 0,47 \\
\hline Effective degree of saturation $\left(\mathrm{S}_{\mathrm{e}}\right)$ & 0,77 & 0,67 & 0,60 & 0,50 & 0,47 & 0,42 & 0,35 & 0,31 & 0,25 & 0,12 \\
\hline \multicolumn{11}{|c|}{ Series B loess - optimally wet samples $\mathrm{w}_{\mathrm{opt}}=19,0 \%$, residual degree of saturation $\mathrm{S}_{\mathrm{rez}}=0,45$} \\
\hline$u_{a}-u_{w}[k P a]$ & 20 & \multicolumn{2}{|l|}{40} & 80 & 150 & 300 & \multicolumn{2}{|l|}{500} & 1000 & 1500 \\
\hline Degree of saturation $\left(\mathrm{S}_{\mathrm{r}}\right)$ & 0,88 & \multicolumn{2}{|l|}{0,84} & 0,82 & 0,80 & 0,78 & \multicolumn{2}{|l|}{0,75} & 0,72 & 0,68 \\
\hline Effective degree of saturation ( $\mathrm{S}_{\mathrm{e}}$ ) & 0,78 & \multicolumn{2}{|l|}{0,71} & 0,67 & 0,64 & 0,60 & \multicolumn{2}{|l|}{0,54} & 0,49 & 0,42 \\
\hline \multicolumn{11}{|c|}{ Series $B$ loess - wet samples $w=22,0 \%$, residual degree of saturation $\mathrm{S}_{\mathrm{rez}}=0,48$} \\
\hline$u_{a}-u_{w}[k P a]$ & 20 & \multicolumn{2}{|l|}{40} & 80 & 150 & 300 & \multicolumn{2}{|l|}{600} & 1000 & 1500 \\
\hline Degree of saturation $\left(\mathrm{S}_{\mathrm{r}}\right)$ & 0,91 & \multicolumn{2}{|l|}{0,90} & 0,88 & 0,87 & 0,85 & \multicolumn{2}{|l|}{0,82} & 0,79 & 0,77 \\
\hline Effective degree of saturation ( $\mathrm{S}_{\mathrm{e}}$ ) & 0,83 & \multicolumn{2}{|l|}{0,81} & 0,77 & 0,75 & 0,71 & \multicolumn{2}{|l|}{0,71} & 0,60 & 0,56 \\
\hline
\end{tabular}

Table 5. Variation of degree of saturation with matric suction for the series $\mathrm{C}$ artificial samples

\begin{tabular}{|c|c|c|c|c|c|c|c|c|}
\hline \multicolumn{9}{|c|}{ Series $\mathrm{C}$ loess - dry samples $w=11,5 \%$, residual degree of saturation $\mathrm{S}_{\mathrm{rez}}=0,13$} \\
\hline$u_{a}-u_{w}[k P a]$ & 20 & 40 & 80 & 160 & 300 & 600 & 1000 & 1300 \\
\hline Degree of saturation $\left(\mathrm{S}_{\mathrm{r}}\right)$ & 0,60 & 0,43 & 0,36 & 0,31 & 0,27 & 0,23 & 0,22 & 0,21 \\
\hline Effective degree of saturation ( $\mathrm{S}_{\mathrm{e}}$ ) & 0,54 & 0,34 & 0,26 & 0,21 & 0,16 & 0,11 & 0,10 & 0,09 \\
\hline \multicolumn{9}{|c|}{ Series C loess - optimally wet samples $w_{\text {opt }}=14,0 \%$, residual degree of saturation $S_{\text {rez }}=0,16$} \\
\hline $\mathrm{u}_{\mathrm{a}}-\mathrm{u}_{\mathrm{w}}[\mathrm{kPa}]$ & 20 & 40 & 80 & 160 & 300 & 600 & 1000 & 1300 \\
\hline Degree of saturation $\left(\mathrm{S}_{\mathrm{r}}\right)$ & 0,68 & 0,48 & 0,39 & 0,35 & 0,29 & 0,28 & 0,27 & 0,25 \\
\hline Effective degree of saturation $\left(\mathrm{S}_{\mathrm{e}}\right)$ & 0,60 & 0,44 & 0,34 & 0,26 & 0,19 & 0,14 & 0,13 & 0,11 \\
\hline \multicolumn{9}{|c|}{ Series C loess - wet samples $w=16,5 \%$, residual degree of saturation $S_{\text {rez }}=0,17$} \\
\hline $\mathrm{u}_{\mathrm{a}}-\mathrm{u}_{\mathrm{w}}[\mathrm{kPa}]$ & 20 & 40 & 80 & 160 & 300 & 600 & 1000 & 1300 \\
\hline Degree of saturation $\left(\mathrm{S}_{\mathrm{r}}\right)$ & 0,73 & 0,55 & 0,47 & 0,41 & 0,36 & 0,29 & 0,28 & 0,27 \\
\hline Effective degree of saturation ( $\mathrm{S}_{\mathrm{e}}$ ) & 0,67 & 0,45 & 0,36 & 0,29 & 0,23 & 0,14 & 0,13 & 0,12 \\
\hline
\end{tabular}

degree of saturation. For pure sand, the residual level is generally obtained at matric suction values of less than 1500 $\mathrm{kPa}$. On the other hand, the determination - quantification of residual level is not so simple for the fine-grained soil. Van Genuchten recommends that the matric suction of $1500 \mathrm{kPa}$ be taken as the residual value [23]. In this paper, the residual level of saturation is determined by successive approximations until all points in the "effective degree of saturation - matric suction" diagram, in logarithmic proportions, are situated along the straight line, after the air-entry value [13]. The values obtained were also checked according to the graphical procedure proposed by Vanapalli [24].

For the same matric suction, the degree of saturation increases with an increase in the percentage of the finegrained soil fraction.

Because of the pore size, the drainage occurs faster in sandy soil compared to silty or clayey soil. The degree of saturation of an optimally wet sample (with the maximum dry bulk density), and for any matric suction value, is greater than the degree of saturation of a dry sample, but lower that the degree of 

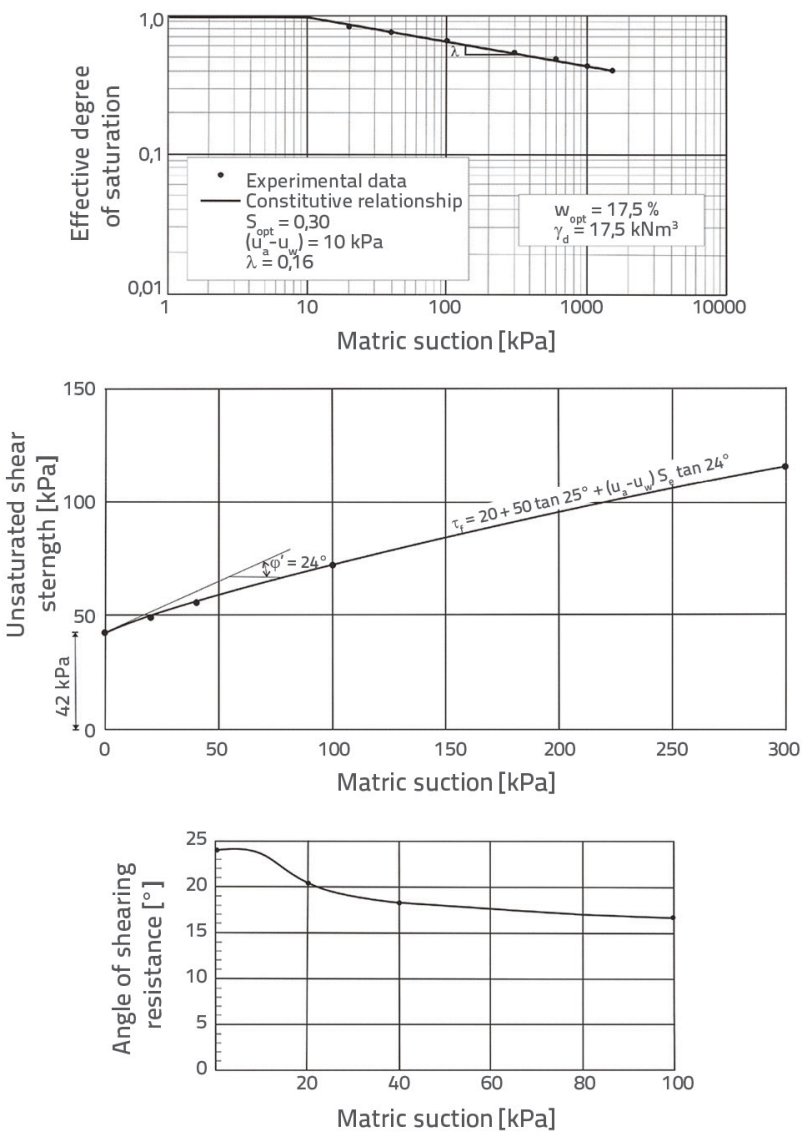

Figure 5. Reltionship between matric suction for an optimally wet sample from series $A$ : a) the effective degree of saturation; b) unsaturated shear strength; c) angle $\varphi^{\mathrm{b}}$
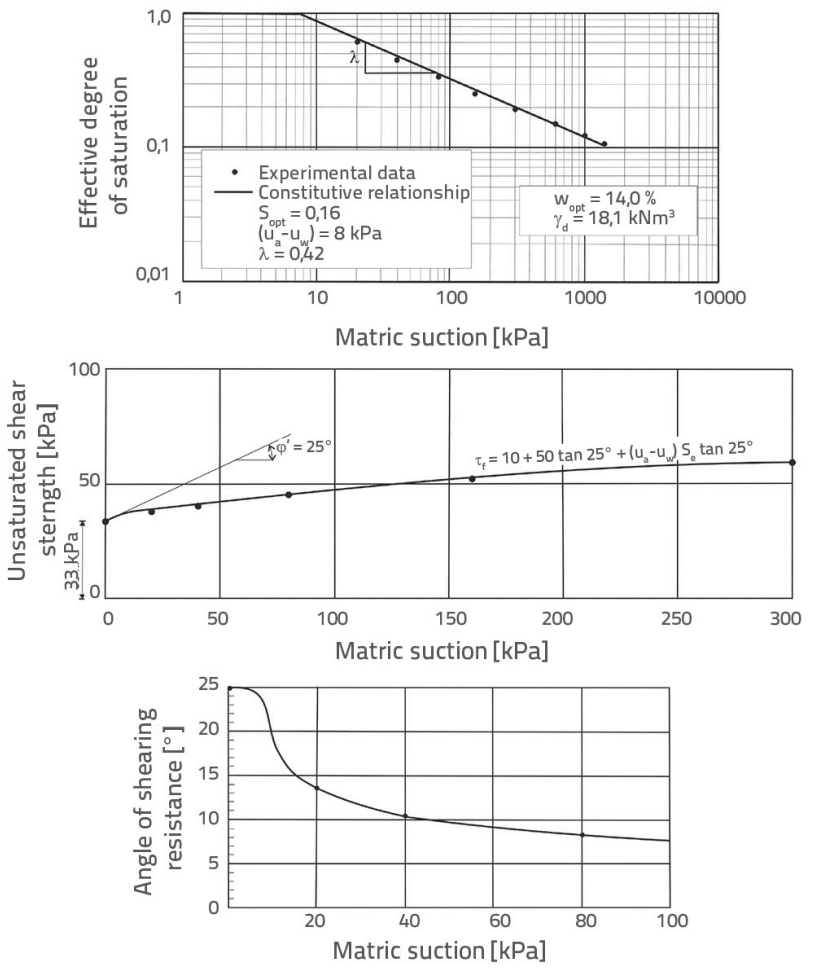

Figure 7. Relationship between matric suction for an optimally wet sample from series $C$ : a) the effective degree of saturation; b) unsaturated shear strength; c) angle $\varphi^{\mathrm{b}}$
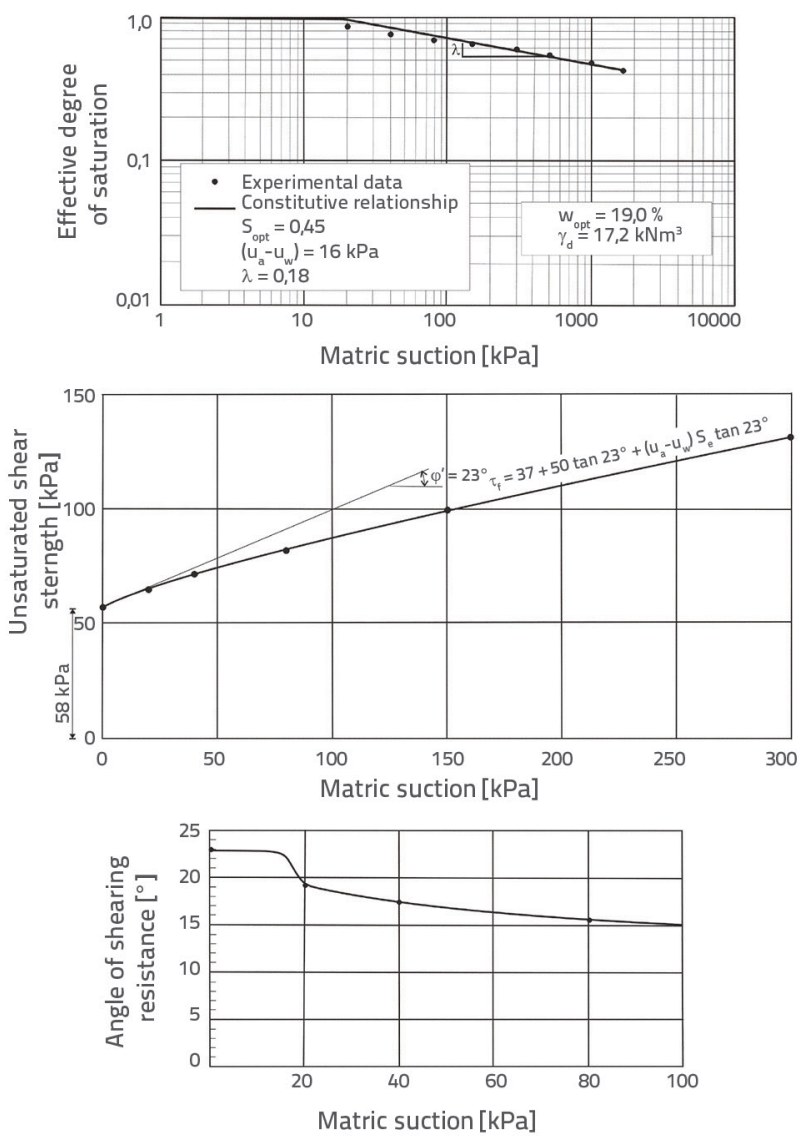

Figure 6. Relationship between matric suction for an optimally wet sample from series $B$ : a) the effective degree of saturation; b) unsaturated shear strength; c) angle $\varphi^{\mathrm{b}}$

saturation of a wet sample. This clearly shows that the grain size and initial moisture [25] have a dominant influence on the relationship between the moisture and matric suction of unsaturated soil.

\subsection{Variation of moisture, shear strength and angle $\varphi^{\mathrm{b}}$ with matric suction}

Relationships between the effective degree of saturation and matric suction, according to expression (1), were determined on the basis of the saturated sample drainage testing in extractor under pressure and the degree of saturation $S_{r}$, which was determined based of sample weight measurements after each extraction level. Relationships between the shear strength of unsaturated soil and matric suction, according to expression (3), and relationships between the shear of unsaturated soil $\varphi^{b}$ and matric suction, according to expression (4), were determined based on the effective degree of saturation $\mathrm{S}_{\mathrm{e}}$ and the effective shear strength parameters for saturated soil, $c^{\prime}$ and $\varphi^{\prime}$.

Results shown in tables for all samples, and in diagrams for some samples, illustrate the influence exerted by different parameters on the variations of moisture, shear strength and angle $\varphi^{\mathrm{b}}$, with matric suction. Diagrams for optimally wet samples belonging to series $A$ (Figure 5), B (Figure 6 ) and C 

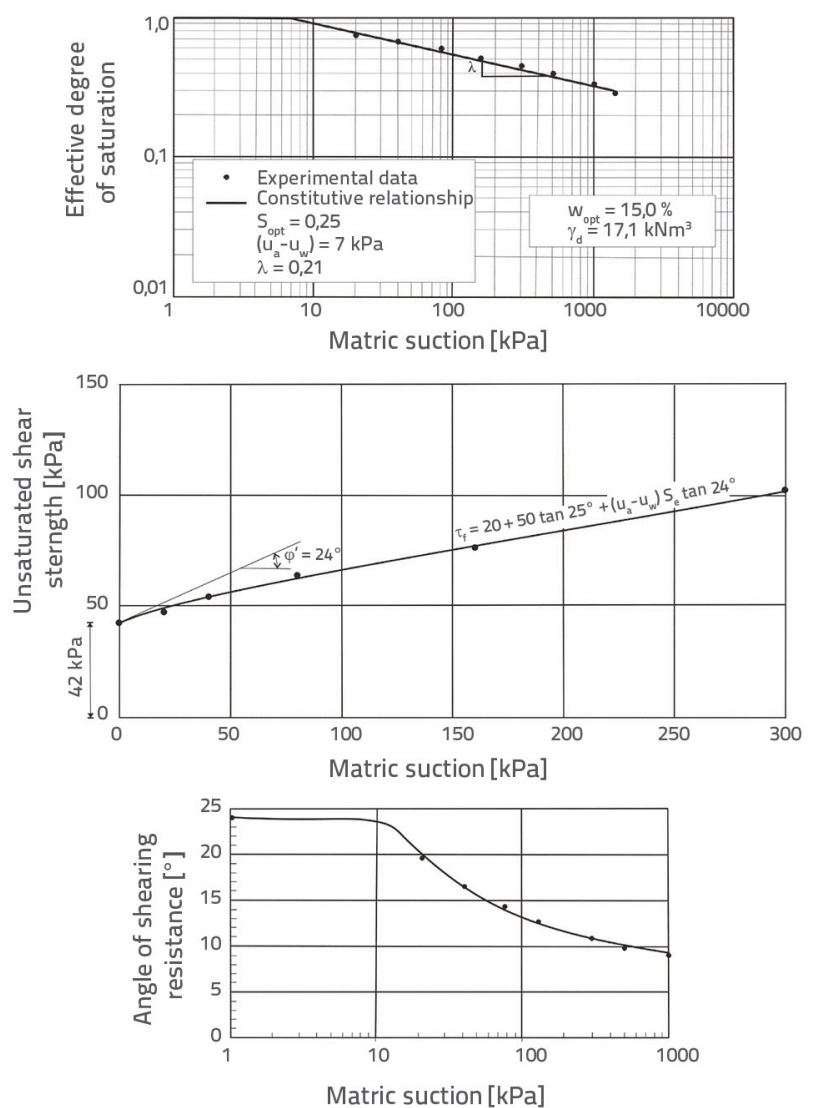

Figure 8. Relationship between matric suction for a dry sample from series $A: a)$ the effective degree of saturation; b) unsaturated shear strength; c) angle $\varphi^{\mathrm{b}}$

(Figure 7) are presented for the analysis of influence of grain size on constitutive relationships. In addition to diagrams for optimally wet samples, diagrams for dry samples (Figure 8) and wet samples (Figure 9) from the same series A, are presented for the analysis of influence of initial moisture and dry bulk weight on constitutive relationships.

\section{Analysis of influence exerted by various parameters}

\subsection{Influence of initial conditions on typical moisture - matric suction curves}

The analysis of results has revealed that the said initial conditions exert influence on the residual degree of saturation, air-entry value, and coefficient $\lambda$.

\subsubsection{Residual degree of saturation}

The residual degree of saturation and residual matric suction increase with an increase in the percent of fine-grained fraction in soil. The residual degree of saturation also increases with an increase in initial moisture.

In case of coarse -grained loose soil, the residual state is
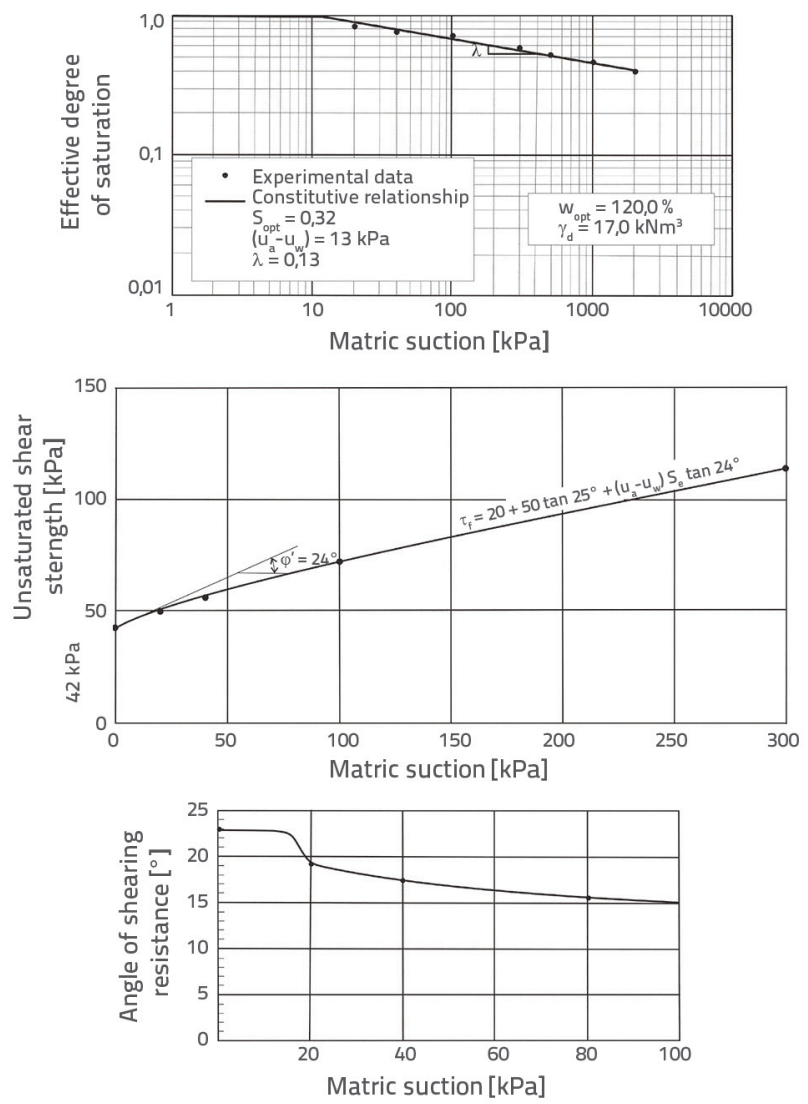

Figure 9. Relationship between matric suction for a wet sample from series A: a) the effective degree of saturation; b) unsaturated shear strength; c) angle $\varphi^{\mathrm{b}}$

realized at lower matric suctions $(0-500 \mathrm{kPa})$ as compared to fine-grained coherent silty, clayey, or clayey-silty types of soil $(500-1500 \mathrm{kPa})$. For medium to highly plastic clays, the residual state occurs beyond $1500 \mathrm{kPa}$, and even then it is hard to define it with accuracy.

Although it is known that the residual matric suction and plasticity index are correlated, a uniform dependence actually does not exist as the same kind of soil with different initial conditions (moisture and dry density) exhibit different moisture - matric suction relationships (SWRC), and hence also different residual suction values. In fact the same kind of soil with different initial water content is bound to behave differently. It can generally be observed that the residual degree of saturation increases with and increase in moisture and assumes the greatest value when the sample is wet.

Residual degree of saturation for silty loess are smaller than similar values (dry, optimally wet and wet samples) for finegrained samples from the series $B$, and greater with regard to coarse-grained samples from the series $C$. They amount to: 0,25 for dry samples, 0.30 for optimally wet samples (with the greatest dry bulk density), and 0.32 for wet samples.

The residual degree of saturation for samples belonging to series B (fine-grained loess) amounts to 0.40 for dry samples, 0.45 for optimally wet samples, and 0.48 for wet samples. 
The residual degree of saturation for samples belonging to series C (coarse-grained loess) amounts to 0.13 for dry samples, 0.16 for optimally wet samples, and 0.17 for wet samples.

The residual degree of saturation $\mathrm{S}_{\text {rez }}$ influences the effective degree of saturation $\mathrm{S}_{\mathrm{e}}$. The effective degree of saturation, $\mathrm{S}_{\mathrm{e}^{\prime}}$ as related to matric suction, varies from one in saturated state to zero in residual state. The effective degree of saturation, $\mathrm{S}_{\mathrm{e}^{\prime}}$ is equal to one in the suction interval from zero to air entry value.

The effective degree of saturation, $\mathrm{S}_{\mathrm{e}^{\prime}}$ gradually reduces once the air entry value is attained $\left(u_{a}-u_{w}\right)_{b}$ and this in parallel with an increase in matirc suction. The effective degree of saturation, $\mathrm{S}_{\mathrm{e}^{\prime}}$ strives toward zero when the soil attains the state of residual matric suction $\left(u_{a}-u_{w}\right)_{\text {rez }}$.

\subsubsection{Air entry value}

The air entry value corresponds to the suction at which the horizontal part of the curve attains a constant slope. Air entry value for dry samples is always smaller when compared to air entry value for optimally wet and wet samples.

For loess samples belonging to series $A$ the air entry value amounts to $7 \mathrm{kPa}$ for dry samples, $10 \mathrm{kPa}$ for optimally wet samples, and $13 \mathrm{kPa}$ for wet samples.

For loess samples belonging to series $B$ the air entry value amounts to $15 \mathrm{kPa}$ for dry samples, $18 \mathrm{kPa}$ for optimally wet samples, and $25 \mathrm{kPa}$ for wet samples.

For loess samples belonging to series $C$ the air entry value amounts to $5 \mathrm{kPa}$ for dry samples, $8 \mathrm{kPa}$ for optimally wet samples, and $10 \mathrm{kPa}$ for wet samples.

\subsubsection{Coefficient $\lambda$}

The coefficient $\lambda$ is the slope of the rectilinear part of the effective degree of saturation - matric suction curve, after value of the matric suction that corresponds to the air entry value.

The coefficient $\lambda$ for loess samples from the series $A$ amounts to: $0.21,0.16$ and 0.13 for dry, optimally wet, and wet samples, respectively. The coefficient $\lambda$ for loess samples from the series B amounts to: $0.18,0.15$ and 0.20 for dry, optimally wet, and wet samples, respectively. The coefficient $\lambda$ for loess samples from the series $C$ amounts to: $0,45,0.42$ and 0.35 for dry, optimally wet, and wet samples, respectively.

According to these results, it can be concluded that the coefficient I increases with an increase in the percent of coarsegrained fraction and with the reduction in initial moisture in soil.

Table 6. Laboratory test results for Canadian till [17]

\subsection{Influence of soil structure on constitutive relationships}

The soil that is compacted with moisture less than an optimum one has an open structure with large interconnected and well passable pores that enable rapid desaturation under the influence of matric suction. The macro pore structure is dominant in the series of dry samples.

The soil that is compacted with moisture in excess of an optimum one has pores that are not interconnected, the pore space is "trapped" and impassable, pore channels are generally disconnected and do not enable desaturation. These samples present effective degree of saturation-matric suction curves with smoother slope when compared to effective degree of saturation-matric suction curves of dry samples.

\subsection{Variation of the unsaturated soil shear strength with matric suction}

Until the suction at which the air penetrates into the pores and the drainage starts, i.e. $\left(u_{a}-u_{w}\right)_{b^{\prime}}$ the suction influence on the shear strength is equivalent to the influence of normal stress on the shear strength, i.e. to the angle $\varphi^{\prime}$. The variation of the unsaturated soil shear strength with matric suction is nonlinear from the air entry value [26]. After that, the influence of suction on the shear strength, expressed with the angle $\varphi^{\text {b }}$, reduces but still exists until the point in which the soil has attained the residual degree of saturation. After that residual degree of saturation, no futher increase in shear strength due to suction is registered.

The influence of matric suction on unsaturated strength reduces with an increase in grain size in soil. Shear strength envelopes clearly show that, for the same matric suction, the strength increases with an increase in moisture and dry bulk density. The influence of initial dry bulk density is however negligible for the sandy loess. Coarse-grained loess samples exhibit very similar strength values and this regardless the initial dry bulk density [27]. It can therefore be concluded that the influence of initial dry bulk density reduces with an increase in dominant grain size.

As the matric suction value increases, samples start to release water from soil pores. Large pores are drained first, and then the process continues with the drainage of small pores. The surface of the air-water membrane between solid particles, which contributes to the increase in shear strength, reduces during desaturation with an increase in suction pressure. This directly leads to the reduction of the angle of shearing resistance, $\varphi^{\mathrm{b}}$, with an increase in suction pressure.

\begin{tabular}{|c|c|c|c|c|c|c|c|c|}
\hline \multirow{2}{*}{ Sample } & \multirow{2}{*}{$\begin{array}{c}\gamma_{\mathrm{d}} \\
{\left[\mathrm{kN} / \mathrm{m}^{3}\right]}\end{array}$} & \multirow[t]{2}{*}{$G_{s}$} & \multirow[t]{2}{*}{ e } & \multirow{2}{*}{$\begin{array}{l}\mathbf{w}_{1} \\
{[\%]}\end{array}$} & \multirow{2}{*}{$\begin{array}{c}\mathrm{I}_{\mathrm{p}} \\
{[\%]}\end{array}$} & \multicolumn{3}{|c|}{ Grain size distribution } \\
\hline & & & & & & Clay [\%] & Silt [\%] & Sand [\%] \\
\hline Canadian till & 17,1 & 264 & 0,55 & 32 & 18,7 & 30 & 42 & 28 \\
\hline
\end{tabular}




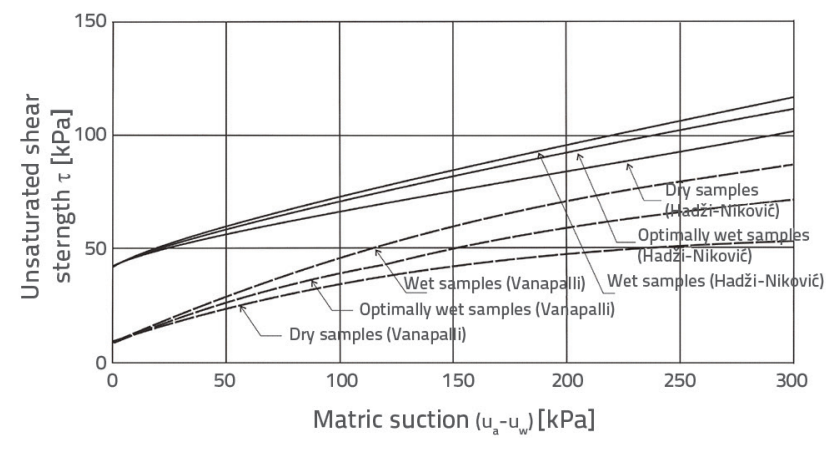

Figure 10. Shear strength of unsaturated soil for the series A silty loess samples and Canadian glacial till, with different initial moisture

The angle $\varphi^{\mathrm{b}}$, increases with an increase in stress and with an increase in initial moisture [18]. Sandy loess samples are under a much smaller influence of stress and initial moisture, compared to loess samples and buried soil.

In case of artificially prepared samples of optimum moisture with the matric suction in the range of $\left(u_{a}-u_{w}\right)=20-100 \mathrm{kPa}$, the angle $\varphi^{\mathrm{b}}$ amounts to: $\varphi^{\mathrm{b}}=21^{0}-15^{\circ}$ for loess samples from series $A_{i} \varphi^{\mathrm{b}}=22^{0}-16^{0}$ for loess samples from series $B, \varphi^{\mathrm{b}}=$ $17^{0}-7^{0}$ for loess samples from series $C$.

\section{Verification of results}

The verification of results was conducted by:

- comparison of results presented in this paper with results obtained by other researchers for similar types of soil;

- verification of non-dimensional parameter $K$ values as obtained on the established relationship between the fitting parameter $\mathrm{K}$ and plasticity index $\mathrm{Ip}$;

Vanapalli conducted very extensive and complex analyses of Canadian till samples, the characteristics of which are presented in Table 6.

Figure 10 shows shear strength results for unsaturated samples of Canadian till and for artificially prepared series $A$ samples, of various moisture and dry bulk density values.

Vanapali [7] also proposed an another expression for the determination of unsaturated strength:

$\tau_{f}=\left[c^{\prime}+\left(\sigma_{n}-u_{a}\right) \tan \varphi^{\prime}\right]+\left(u_{a}-u_{w}\right) \Theta^{K}\left(\tan \varphi^{\prime}\right)$

where:

$\mathrm{K}$ - fitting parameter that is used to obtain a better correlation between predicted and measured shear strength values,

Q $-\mathrm{w} / \mathrm{w}_{\mathrm{s}}$

W - water content after drainage by a matric suction value $\left(\mathrm{u}_{\mathrm{a}}-\mathrm{u}_{\mathrm{w}}\right)$,

$w_{s}$ - water content in saturated state.

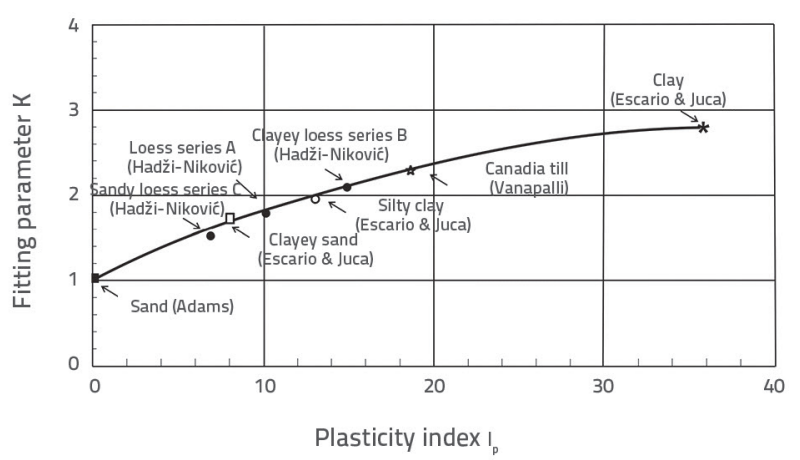

Figure 11. The relationship between the fitting parameter $\mathrm{K}$ and plasticity index Ip

Based on this expression, we retroactively determined the parameter $K$ value, and we presented the results on the diagram where the parameter $K$ - plasticity index $I_{p}[11]$ relationship was already established (Figure 11).

It can be seen from the diagram that a good correspondence for loess sediments series $A, B$ and $C$, exists with the established relationship between the fitting parameter $\mathrm{K}$ and the plasticity index $I_{p}$.

\section{Conclusion}

An increase in shear strength of unsaturated soil, as related to the shear strength of saturated soil, is expressed by means of an angle $\varphi^{\text {b }}$. Relationships between shear strength and matric suction, based on the relationships between the effective degree of saturation - matric suction, were determined for artificial samples of loess soil, of various grading, prepared under different initial conditions. The relationships between the angle $\left(\varphi^{b}\right)$ and matric suction was also established. An increase in shear strength due to matric suction is dependent on the soil drainage rate. Samples that exhibit a higher effective degree of saturation also exhibit a greater strength for the same normal stress and the same matric suction. Although volume changes can be highly significant in case of change in moisture of a compacted unsaturated soil [28], these changes have not been studied during this research. It is known that their significance increases with an increase in soil plasticity [29]. As results obtained by testing soil with the plasticity indices of $I_{p}=7-15$ are presented in this paper, we considered that their influence on the results obtained is not great. However, some deviations of measured results from the model show that these changes should certainly be taken into account in this kind of research.

Relatively simple procedures and laboratory equipment used in this research can conveniently be used for the determination of the increase in shear strength of unsaturated compacted soil due to existence of matric suction, but primarily for silty soil. The applicability of this procedure decreases with the 
reduction in grain size and increase in soil plasticity index. Relevant research has confirmed that the influence of initial conditions on the unsaturated strength of compacted soil is significant. This primarily concerns the grain size distribution and initial moisture of soil. The increase in grain size in soil brings about reduced influence of the matric suction, moisture and dry bulk density on the unsaturated strength of compacted loess soil.

\section{REFERENCES}

[1] Fredlund, D.G.: Unsaturated soil mechanics in engineering practice, Journal of geotechnical and geoenvironmental engineering ASCE, Vol. 132, Issue 3, pp. 286-321, 2006.

[2] Boreli, M.: Podzemna voda u zoni aeracije tretirana jednačinama strujanja vode u nezasićenim sredinama, Seminar: Bilans podzemnih voda, Naučna redakcija publikacije: M. Boreli, Jugoslovenski komitet za međunarodnu hidrološku deceniju, pp. 87-118, Beograd, 20.12.1966. - 10.1.1967.

[3] Gens, A.: The development of unsaturated soil mechanics, Zbornik referata Šukljetovi dnevi 14. Slovensko geotehniško društvo, Ljubljana, pp 1-35, Oct. 2013.

[4] Hadži-Niković, G.: Konstitutivne zavisnosti nezasičenih tla područja Beograda - doktorska disertacija, Rudarsko-geološki fakultet, Univerzitet u Beogradu, 247 p. 2005.

[5] Hadzi-Nikovic, G.: Effect of soil suction on slope stability in natural residual soil, 12 Danube-European Conference, Geotechnical Engineering, Passau, Germany, pp. 223-226, 2002.

[6] Hadzi-Niković, G.: The slope stability in unsaturated overconsolidated clayey soil, Proc.IAEG, Durban, South Africa, 2002.

[7] Vanapalli, S.H., Fredlund, D.G., Pufahl, D.E., Clinton, A.W.: Model for the prediction of shear strength with respect to soil suction, Canadian Geotechnical Journal 33, No 3, pp. 379-392, 1996.

[8] ASTM D 2325-68, Standard Test Method for Capillary-Moisture Relationships for Coarse- and Medium Textured Soils by Porous-Plate Apparatus.

[9] ASTM D 3152-72, Standard Test Method for Capillary-Moisture Relationships for Fine-Textured Soils by Pressure-Membrane Apparatus.

[10] Vanapalli, S.H., Fredlund, D.G., Pufahl, D.E.: The relationship between the soil-water characteristic curve and the unsaturated shear strength of a compacted glacial till, Geotechnical Testing Journal 19/ 3, pp. 259-268, 1996.

[11] Vanapalli, S.K., Fredlund, D.G.: Comparison of different procedures to predict unsaturated soil shear strength, Proc. Geo Denver Conf ASCE Special Publication, No 99, Reston, Va, pp. 195-209, 2000.

[12] Terzaghi, K.: Theoretical Soil Mechanics, John Wiley and Sons, Inc. New York, 1936.

[13] Fredlund, D.G., Rahardjo, H.: Soil mechanics for unsaturated soils, Wiley \& Sons, New York, 1993.

[14] Barbour, S.L.: The soil-water characteristic curve - a historical perspective and application to the behaviour of unsaturated soils, Canadian Geotechnical Journal 35, pp. 873-894,1998.
[15] Fredlund, D.G., Morgenstern, N.R., Widger, R.A.: The shear strength of unsaturated soils, Canadian Geotechnical Journal 13, pp. 261-275, 1976.

[16] Fredlund, D.G., Xing, A., Fredlund, M.D., Barbour, S.L.: The relationship of the unsaturated soil shear strength function to the soil-water characteristic curve, Canadian Geotechnical Journal 33, No 3, pp. 440-448, 1996.

[17] Guan, G.S., Rahardjo, H., Choon, L.E.: Shear strength equations for unsaturated soil under drying and wetting, Journal of geotechnical and geoenvironmental engineering ASCE, Vol. 136, No. 4, pp. 594-606, 2010.

[18] Vanapalli, S.K., Fredlund, D.G.: Empirical procedures to predict the shear strength of unsaturated soils, 11th Asian Regional Conference on Soil Mechanics and Geotechnical Engineering, Seoul, Vol.1, pp. 93-96, 1999.

[19] Brooks, R.H., Corey, A.T.: Hydraulic properties of porous media, Colorado State Univ. Hydrol. Paper No.3, 27 pp., Mar. 1964.

[20] SRPS U.B1.038: Određivanje odnosa vlažnosti i suve zapreminske mase tla, 1997.

[21] Vanapalli, S.K.: Personal correspondence, Jan. 2004. Ph.D.P.Eng. Professor at Faculty of Engineering, Ottawa University, Canada.

[22] SRPS U.B1.028: Opit direktnog smicanja tla, 1996.

[23] Van Genuchten, M.T.: A closed-form equation for predicting the hydraulic conductivity of unsaturated soils. Soil Science Society of America Journal, 44. 892-898, 1980.

[24] Vanapalii, S.K.: Simple test procedure and their interpretation in evaluating the shear strength of an unsaturated soil, PhD Thesis, University of Saskatchewan, Saskatoon, Canada, 1994.

[25] Marinho, F.A.M., Oliveira, O.M., Adem, H., Vanapalli, S.: Shear strength behaviour of compacted unsaturated residual soil, International Journal of Geotechnical Engineering, Vol.7, No 1, pp 1-9, 2013.

[26] Sheng, D., Zhou, A., Fredlund, D.G.: Shear strength criteria for unsaturated soils, Geotechnical and Geological Engineering, No 29, Issue 2, pp. 145-159, 2011.

[27] Hadži-Niković, G.: The influence of the grain-size distribution and soil structure on the unsaturated shear strength of loess sediments in Belgrade, Anaales Geologiques de la Peninsule Balkanique No 70, 83-91, 2009.

[28] Maček, M., Majes, B., Petkovšek, A.: Influence of mould suction on the volume-change behavior of compacted soils during inundation. Journal Acta Geotechnica Slovenica, 2011-2, article 5. 2011.

[29] Kavur, B., Vrkljan, I., Kovačić Zelić, B.: Analysis of hydraulic properties of unsaturated expansive soil, Građevinar 63 (2011), 3, pp. 245-253. 